\title{
Kathmandu, Nepal
}

\author{
Shidiki Amrullah ${ }^{* 1}$, Bhargava Dipak ${ }^{1}$, Gupta Ravi Shankar ${ }^{1}$, Ansari Akhtar Alam² Pandit Bijay Raj ${ }^{1}$ \\ ${ }^{1}$ Department of Microbiology, National Medical College, Birgunj, Parsa, Nepal \\ ${ }^{2}$ Department of Pharmacology, National Medical College, Birgunj, Nepal
}

\section{ABSTRACT}

Background: This study reports the comparative studies and microbial risk assessment of different water samples used for drinking water. The results obtained were compared with WHO and EPA standards for drinking and recreational water.

Methods: Physicochemical and bacteriological analysis of water samples were carried out from source, taps, well and stone spouts used for drinking purpose in Tokha (Saraswati and Chandeswari Village Development Committee). Total viable count was carried out by pour plate technique. Total coliform and fecal coliform were performed by membrane filtration technique. The results obtained were compared with World Health Organization (WHO), National Agency for Food and Drug Administration and Control (NAFDAC) and Nepal Standard of Drinking Water Quality (NSDWQ) standards for drinking water.

Results: The $\mathrm{pH}$, total hardness, chloride, nitrate and arsenic content of samples were found within permissible guideline value however well sample was found to exceed Nepal standard values for calcium hardness and ammonia content. The total viable counts for all the water samples were high exceeding the limit for water $\left(1.0 \times 10^{2} \mathrm{cfu} /\right.$ $\mathrm{ml})$. All the water samples were found to contain coliforms and fecal organisms in numbers greater than the required $\mathrm{WHO} / \mathrm{FAO}$ standards for water. The fecal coliform colonies on $\mathrm{M}$-endo agar plate ranged between 143 and 152 and total coliform from 110 to 248 per $100 \mathrm{ml}$ water also exceed the standard limit for water. The Isolated organisms were identified to be E.coli, Klebsiella spp. and Citrobacter spp.

Keywords: Analysis, Bacteriological, Drinking water, Nepal, Physicochemical

Corresponding Author: Amrullah Shidiki, Department of Microbiology, National Medical College and Teaching Hospital, Birgunj (Parsa), Nepal; E-mail: amarullahsidhiqie24@gmail.com

\section{INTRODUCTION}

Water of good drinking quality is of basic importance to human physiology. ${ }^{1}$ The provision of portable water to the rural and urban population is necessary to prevent health hazards., ${ }^{2,3}$ Before water can be described as potable, it has to comply with certain physical, chemical and microbiological standards, which are designed to ensure that the water is palatable and safe for drinking. ${ }^{4}$

Unfortunately clean, pure and safe water only exists briefly in nature and is immediately polluted by prevailing environmental factors and human activities. Water from most sources is therefore unfit for immediate consumption without some sort of treatment. ${ }^{5}$ The consequences of waterborne bacteria and virus infections; polio, hepatitis, cholera, typhoid, diarrhoea, stomach cramps have been well established but nitrate contamination is just as deadly. Contamination of drinking water from any source is of primary importance because of the danger and risk of water borne diseases. ${ }^{6,7}$ 
According to WHO estimate, about $80 \%$ of the third world diseases are transmitted by polluted water. Due to the lack of safe and protective water supply and sanitation, more than 15 million children below five years die each year. ${ }^{8}$ According to public health department of the Government of Nepal (1990), about 443,000 children die every year due to gastroenteritis by drinking contaminated water. The recent example of the epidemic is in the western and mid western region of Nepal where more than 500 deaths have occurred.

In Nepal, Tokha Village Development Committee (VDC) doesn't have proper water supply system. Drinking water is obtained from surface sourceriver. Such natural water supply is likely to be polluted with domestic and industrial wastes. This work is therefore, in an attempt to examine the different sources of drinking water in this VDC and to compare with standard table water for conformity to microbiological and physicochemical standards for supply water samples as well as to examine the different domestic and industrial effluents/waste water for conformity to standards for effluent discharges.

\section{MATERIALS AND METHODS}

The water samples were collected randomly from taps, sources and reservoir from the area of VDC Tokha, Kathmandu. Water was collected in the pre-sterilized biological oxygen demand bottle and clean plastic bottle for microbial and physic-chemical analysis. For tap and source water, bottle was cleaned with alcohol and left water for 2 minutes and finally filled from slow flow of water. For reservoir water, the bottle was placed in the tank at a depth of 15 to $30 \mathrm{~cm}$. After collection, samples were processed at laboratory of National College Kathmandu, Nepal following standard methods with APHA American public health association, 1995.

For microbial analysis, water samples were processed for serial dilution, standard plate count and standard total coliform count by membrane filter procedure. Colonies from M-Endo agar, XLD agar and TCBS agar after 48 hours incubation were sub-cultured onto NA agar for pure culture. Isolated bacteria were identified on the basis of their colonial characteristic, morphological characteristics and biochemical properties according to Bergey's Manual of Determinative Bacteriology, 1994. Physicochemical analysis like temperature, $\mathrm{p}^{\mathrm{H}}$, total hardness, calcium, chloride, nitrate, arsenic and ammonia were identified according to WHO guideline, 1998.

\section{RESULTS}

Out of twenty three samples from public taps, wells, stone-spouts and source, $\mathrm{pH}$ values of all water samples were found similar in level with Nepal Standard values. From well, the values of calcium hardness and ammonia content were more than Nepal standard. Total hardness content was found same within the standard guide-line values. The nitrate and arsenic content of all samples were same within permissible level. The bacteriological analysis for total coliform and faecal coliformrevealed most frequently E.coli and Citrobacter. Water from taps and Inar (T1, T5, T6, T11, T16, T18, T19, and I1 \& I2) contained coliforms ( $>300 \mathrm{cfu} / 100 \mathrm{ml})$.

\section{DISCUSSION}

The temperature of the water was found in the range of $20^{\circ} \mathrm{C}$ to $22^{\circ} \mathrm{C}$. This temperature range of $28^{\circ} \mathrm{c}-30^{\circ} \mathrm{c}$ of water has been influenced by the intensity of the sunlight as temperature rise from $28^{\circ} \mathrm{c}-30^{\circ} \mathrm{c}$ on relatively hot days. ${ }^{9}$ The temperature range of $26^{\circ} \mathrm{c}-30^{\circ} \mathrm{c}$ is due to the insulating effect of increased nutrient load resulting from industrial discharge. ${ }^{10}$ The samples have neutral $\mathrm{p}^{\mathrm{H}}(7-7 \cdot 89)$. The $\mathrm{pH}$ of most natural waters ranges from 6.5-8.5 while deviation from the neutral as a result of the $\mathrm{CO} 2 /$ bicarbonate/carbonate equilibrium. ${ }^{11}$

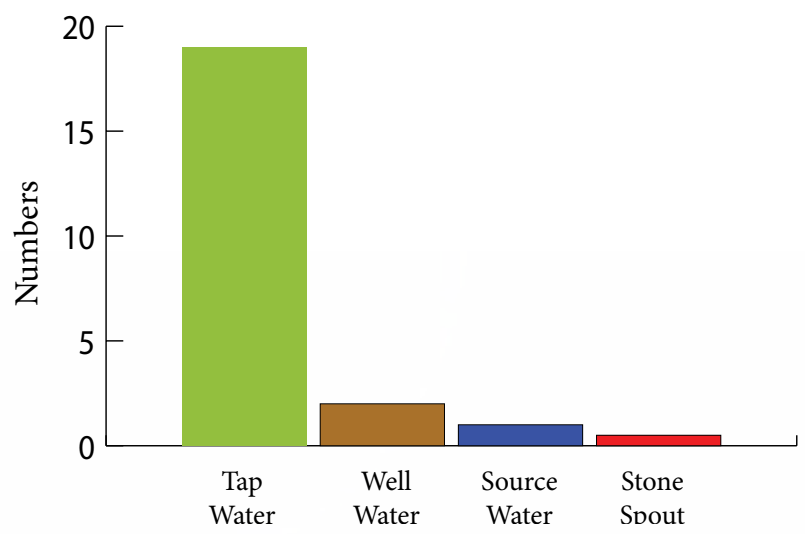

Figure 1: Sample Size 
Table 1: Physicochemical parameters of water

\begin{tabular}{|c|c|c|c|c|c|c|c|c|c|}
\hline Sample & $\begin{array}{l}\text { Tem } \\
{ }^{\circ} \mathrm{C}\end{array}$ & $\begin{array}{c}\mathrm{pH} \\
7.0-8.5\end{array}$ & $\begin{array}{c}\text { Total } \\
\text { Hardness } \\
500 \mathrm{mg} / 1\end{array}$ & $\begin{array}{l}\text { Calcium } \\
\text { hardness } \\
200 \mathrm{mg} / \mathrm{l}\end{array}$ & $\begin{array}{c}\text { Magnesium } \\
\text { Hardness } \\
\text { mg/l }\end{array}$ & $\begin{array}{l}\text { Nitrate } \\
50 \mathrm{mg} / \mathrm{l}\end{array}$ & $\begin{array}{l}\text { Arsenic } \\
0.05 \mathrm{mg} / \mathrm{l}\end{array}$ & $\begin{array}{l}\text { Chloride } \\
250 \mathrm{mg} / \mathrm{l}\end{array}$ & $\begin{array}{c}\text { Ammonia } \\
1.5 \mathrm{mg} / \mathrm{l}\end{array}$ \\
\hline $\mathrm{T} 1$ & 20 & 7.5 & 23 & 7 & 16 & 2 & 0 & 12.78 & 0 \\
\hline $\mathrm{T} 2$ & 20 & 7.25 & 14 & 5 & 9 & 2 & 0 & 9.23 & 0.5 \\
\hline $\mathrm{T} 3$ & 21 & 7.47 & 9 & 7 & 2 & 2 & 0 & 8.52 & 0 \\
\hline $\mathrm{T} 4$ & 21 & 7.6 & 11 & 26 & 15 & 2 & 0 & 9.94 & 0 \\
\hline $\mathrm{T} 5$ & 20 & 7.19 & 24 & 32 & 8 & 2 & 0 & 7 & 0 \\
\hline T6 & 21 & 7.2 & 24 & 10 & 14 & 2 & 0 & 7.1 & 0 \\
\hline $\mathrm{T} 7$ & 21 & 7.67 & 124 & 64 & 60 & 2 & 0 & 46.86 & 0 \\
\hline $\mathrm{T} 8$ & 21 & 7.64 & 140 & 0 & 0 & 0 & 0 & 0 & 0 \\
\hline W1 & 21 & 7.89 & 324.6 & 242 & 82.6 & 8 & 0 & 68.16 & 1 \\
\hline W2 & 20 & 7.56 & 64 & 378 & 226 & 8 & 0 & 231.46 & $>3$ \\
\hline T9 & 20 & 7.45 & 11 & 8 & 3 & 2 & 0 & 9.23 & 0 \\
\hline $\mathrm{T} 10$ & 20 & 7.05 & 10 & 15 & 5 & 2 & 0 & 7.81 & 0 \\
\hline $\mathrm{T} 11$ & 20 & 7.05 & 11 & 8 & 3 & 2 & 0 & 10.65 & 0 \\
\hline $\mathrm{T} 12$ & 21 & 7.52 & 27 & 96 & 69 & 2 & 0 & 7.1 & 0 \\
\hline $\mathrm{T} 13$ & 21 & 7.27 & 23 & 31 & 8 & 2 & 0 & 7.1 & 0 \\
\hline $\mathrm{T} 14$ & 21 & 7.56 & 21 & 34 & 13 & 2 & 0 & 6.39 & 0 \\
\hline $\mathrm{T} 15$ & 20 & 7.57 & 21 & 35 & 14 & 2 & 0 & 7.81 & 0 \\
\hline T16 & 21 & 7.55 & 24 & 0 & 0 & 0 & 0 & 0 & 0 \\
\hline $\mathrm{T} 17$ & 20 & 7.57 & 24 & 13 & 11 & 2 & 0 & 8.52 & 0 \\
\hline $\mathrm{T} 18$ & 20 & 7.17 & 26 & 18 & 8 & $\leq 2$ & 0 & 9.94 & 0 \\
\hline T19 & 20 & 7.51 & 24 & 16 & 8 & $\leq 2$ & 0 & 7.1 & 0 \\
\hline $\mathrm{S}$ & 20 & 7.56 & 18 & 26 & 8 & - & 0 & - & 0 \\
\hline SS & 22 & 7.64 & - & 55 & - & 2 & 0 & 6.39 & 0.2 \\
\hline
\end{tabular}

Table 2: Microbiological parameters

\begin{tabular}{|c|c|c|c|c|}
\hline SN & Sample & $\begin{array}{l}\text { Total bacteria } \\
\text { count }(\mathrm{CFU} / \mathrm{ml})\end{array}$ & $\begin{array}{l}\text { Total Coliform at } 37^{\circ} \mathrm{c} \text { ( per } \\
\qquad 100 \mathrm{ml})\end{array}$ & $\begin{array}{l}\text { Fecal coliforms at } 44^{\circ} \mathrm{c} \\
(\text { per } 100 \mathrm{ml})\end{array}$ \\
\hline 1 & $\mathrm{~T} 1$ & $141 \times 10^{4}$ & TMTC & 140 \\
\hline 2 & $\mathrm{~T} 2$ & $67 \times 10^{4}$ & 113 & 104 \\
\hline 3 & $\mathrm{~T} 3$ & $241 \times 10^{4}$ & 228 & 199 \\
\hline 4 & $\mathrm{~T} 4$ & $100 \times 10^{4}$ & 128 & 112 \\
\hline 5 & T5 & $8 \times 10^{4}$ & TMTC & 112 \\
\hline 6 & T6 & $10 \times 10^{4}$ & TMTC & 156 \\
\hline 7 & $\mathrm{~T} 7$ & $101 \times 10^{4}$ & 144 & 112 \\
\hline 8 & T8 & $150 \times 10^{4}$ & 144 & 104 \\
\hline 9 & T9 & $134 \times 10^{4}$ & 240 & 152 \\
\hline 10 & $\mathrm{~T} 10$ & TMTC & 168 & 145 \\
\hline 11 & $\mathrm{~T} 11$ & $120 \times 10^{4}$ & TMTC & 145 \\
\hline 12 & $\mathrm{~T} 12$ & $2 \times 10^{4}$ & 165 & 136 \\
\hline 13 & $\mathrm{~T} 13$ & $2 \times 10^{4}$ & 168 & 154 \\
\hline 14 & $\mathrm{~T} 14$ & $8 \times 10^{4}$ & 184 & 104 \\
\hline
\end{tabular}




\begin{tabular}{|c|c|c|c|c|}
\hline SN & Sample & $\begin{array}{c}\text { Total bacteria } \\
\text { count(CFU/ml) }\end{array}$ & $\begin{array}{c}\text { Total Coliform at } \mathbf{3 7}^{\circ} \mathbf{c}(\mathbf{p e r} \\
\mathbf{1 0 0 \mathrm { ml } )}\end{array}$ & $\begin{array}{c}\text { Fecal coliforms at } \mathbf{4 4}^{0} \mathbf{c} \\
(\mathbf{p e r} \mathbf{1 0 0} \mathbf{m l})\end{array}$ \\
\hline 15 & T15 & $15 \times 10^{4}$ & 136 & 60 \\
\hline 16 & T16 & $25 \times 10^{4}$ & TMTC & 222 \\
\hline 17 & T17 & $65 \times 10^{4}$ & 264 & 172 \\
\hline 18 & T18 & $20 \times 10^{4}$ & TMTC & 145 \\
\hline 19 & T19 & $1 \times 10^{4}$ & TMTC & 250 \\
\hline 20 & W1 & TMTC & TMTC & 148 \\
\hline 21 & W2 & TMTC & TMTC & 178 \\
\hline 22 & S & $204 \times 10^{4}$ & 248 & 152 \\
\hline
\end{tabular}

The fluctuations in $\mathrm{pH}$ lead to an increase or decrease in the toxicity of poisons in water bodies. ${ }^{12}$ The samples showed hardness within the normal level while one of the sample (I1) showed greater value than normal. The calcium content of the water bodies fluctuates directly with bicarbonates and both of these moves inversely with carbonates and $\mathrm{P}^{\mathrm{H}}$. $\mathrm{NH}_{3}$ was found within normal range except one sample I2 $(\geq 3)$ which exceeded WHO guideline value $(1.5 \mathrm{mg} / \mathrm{l})$. Similar results were found in the ground water samples of Kathmandu valley. Water samples were positive for total coliforms. The quality of water has deterioted due to poor management and no monitoring of water quality. Isolated bacteria were the family of Enterobacteriacea.

The identified organisms include E.coli, Klebsiella species, Citrobacter species. Isolation of E.coli was highest among isolates since this organism is abundant in human and animal faeces. The water was faecally contaminated and treatment was ineffective.

\section{CONCLUSION}

Thepathogenic organicand theindicatororganisms present in all the water samples rendered them unfit for human consumption though they can be used for other purposes. Water should meet different quality specifications depending on the particular uses. Thus, potable and domestic water should be harmless for the health of man and should have proper organoleptic properties and should be suitable for domestic use. Water quality should be controlled in order to minimize acute problem of water related diseases, which are endemic to the health of man.

\section{REFERENCES}

1. Lamikaran A. Essential Microbiology for students and Practitioners of Pharmacy, Medicine and Microbiology. 2nd Edn. Amkra books; 1999.p.406.

2. Nikoladze GDM, Akastal S. Water treatment for Public and Industrial Supply MIR Publisher Moscoul; 1989.p.163.

3. Lemo O. Bacteriology Determination of Water with long term storage [dissertation]; Tribhuvan University, 2002.

4. Tebutt THY. Principles of Quality Control. Pergamon, England;1983. p.235.

5. Raymond F. Le Problame dis ean dans le monde (problems of water), EB and Sons Ltd., UK; 1992.p.123-6.

6. Edema MO, Omemu AM, Fapetu OM. Microbiology and Physicochemical Analysis of different sources of drinking water in Abeokuta. Nigeria. Niger. J Microbiol 2001;15(1):57-61.

7. Fapetu OM. Comparative Analysis of Different Sources of Drinking Water in Abeokuta South L.G A., Ogun State [dissertation] UNAAB Abeokuta;2000.p. 44.

8. WHO. Guidelines for drinking- water quality, 1999 Volume 2, 2nd edition, A.I.T.B.S. Publishers and distributors, Delhi.

9. Mulusky DS. Ecology of Estuaries. Heinemann Educational Books, London;1974. pp.5-103.

10. Banwo K. Nutrient Load and Pollution Study of Some Selected Stations along Ogunpa River in Ibadan, Nigeria. [Dissertation].University of Ibadan; 2006. p. 107 .

11. Medera V, Allen HE, Minear RC. Non metallic constituents; Examination of Water Pollution Control. A reference handbook Physical, Chem. Radiol. Exam1982;2:169-357.

12. Ali J. An Assessment of the Water Quality of Ogunpa River Ibadan, Nigeria. [Dissertation]. University of Ibadan; 1991.

Cite this article as: Shidiki A, Bhargava D, Gupta RS, Ansari AA, Pandit BR. Bacteriological and physicochemical analysis of drinking water in Tokha, Kathmandu, Nepal. MED PHOENIX 2016;1(1):15-18 